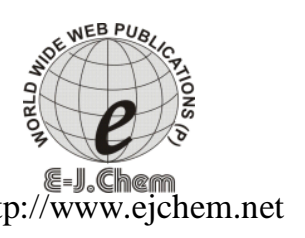

\title{
Synthesis, Spectral and Thermal Behavior of Some New Four Coordinated Complexes
}

\author{
M. MONTAZEROZOHORI ${ }^{1 *}$, S. KHANI $^{1}$, S. JOOHARI $^{2}$ AND S. A. MUSAVI ${ }^{1}$ \\ ${ }^{1}$ Department of Chemistry, Yasouj University, Yasouj, 7591874831, Iran \\ ${ }^{2}$ Department of Basic Science, Yasouj Branch, Islamic Azad University, Yasouj, Iran \\ mmzohori@mail.yu.ac.ir
}

Received 18 August 2011; Accepted 04 October 2011

\begin{abstract}
A new symmetric bidentate Schiff base $N, N^{\prime}$ bis(4-fluorobenzaldehydene)-1,2-diaminoethane(L) and its complexes with general formula $\mathrm{MLX}_{2}(\mathrm{M}=\mathrm{Zn}(\mathrm{II}), \mathrm{Cd}(\mathrm{II})$ and $\mathrm{Hg}(\mathrm{II})$ and $\mathrm{X}=$ chloride, bromide, iodide, thiocyanate and azide) have been prepared. The ligand and complexes have been established by microanalysis, electronic, FT-IR, ${ }^{1} \mathrm{H}$ and ${ }^{13} \mathrm{C}$ NMR spectra, and by molar conductivity measurements. All compounds are non-electrolytes in chloroform or DMSO- $\mathrm{d}_{6}$. The thermal behavior of the complexes shows weight loss by decomposition of the anions and ligand segments in the subsequent steps. Some activation thermodynamic parameters such as $\mathrm{E}^{*}, \Delta \mathrm{H}^{*}$, $\Delta \mathrm{S}^{*}$ and $\Delta \mathrm{G}^{*}$ were calculated from thermal analysis.
\end{abstract}

Keywords: Schiff base ligand, Azomethine, Metal Complex, Spectra, Thermal

\section{Introduction}

Compounds containing azomethine group $(\mathrm{RC}=\mathrm{N}-)$ were named Schiff base after Hugo Schiff $^{1}$ and are usually formed by the condensation of a primary amine with an active carbonyl compound. Schiff base metal complexes with Schiff base ligands have been prepared and presented in numerous reports ranging from the purely synthetic ${ }^{2-8}$ to modern physicochemically such as catalytic application ${ }^{9}$, optical material ${ }^{10}$, dyes, luminophores ${ }^{11}$ and polymer with conductance properties ${ }^{12}$ to biochemically relevant studies of these complexes in the points of view such as biologically active substances, antitumor ${ }^{13}$, antivirial $^{14}$ and antifungal ${ }^{15}$. Because of these applications, synthesis of new Schiff bases and their metal complexes are still the aim of many recent investigations.

In continuation of our previous reports on Schiff base complexes ${ }^{16-18}$, the aim of this work is to prepare and investigate the structure of the chelates of zinc(II), cadmium(II) and mercury(II) with a new bidentate Schiff base ligand as $N, N^{\prime}$ bis(4-fluorobenzaldehydene)1,2-diaminoethane(L) with nitrogen atoms as donor sites. The general formula of these complexes are $\mathrm{MLX}_{2}$ in which $\mathrm{L}=$ bidentate Schiff base ligand Furthermore, thermal behavior of them was investigated and some activation thermodynamic parameters such as A, $E^{*}, \Delta H^{*}, \Delta S^{*}$ and $\Delta G^{*}$ were calculated from thermal analysis. 


\section{Experimental}

All the solvents used in the synthesis and analysis, 4-florobenzaldehyde, ethylenediamine, zinc, cadmium and mercury salts and other chemicals were purchased from Aldrich and Merck, and used without any further purification. The FT-IR spectra were recorded on the JASCO-680 model in the range of $400-4000 \mathrm{~cm}^{-1}$ using a $\mathrm{KBr}$ disk. Elemental analysis (C, N and $\mathrm{H}$ ) was conducted on a CHNS-932(leco) elemental analyzer. UV-Vis spectra in the 200$800 \mathrm{~nm}$ range were recorded using a JASCO-V570 spectrometer at chloroform and DMSO. ${ }^{1} \mathrm{H}$ and ${ }^{13} \mathrm{C}$ NMR spectra were recorded using a Brucker DPX FT-NMR spectrometer at $500 \mathrm{MHz}$ whit the samples dissolved in DMSO- $\mathrm{d}_{6}$ using TMS as internal standard. Molar conductance of the Schiff base ligands and their transition metal complexes were determined in chloroform and DMSO $\left(1.0 \times 10^{-3} \mathrm{M}\right)$ at room temperature using Metrohm 712 conductometer. Thermogravimetric analyses have been obtained with PL-1500 TG Instruments.

Synthesis of Schiff base ligand $(L)$

Ehthylendiamine $(0.060 \mathrm{~g}, 1 \mathrm{mmol})$ was added to 4-fluorobenzaldehyde (0.2482 g, $2 \mathrm{mmol})$ and severally stirred and grinded under solvent free conditions. The white product as Schiff base ligand was formed. Ligand was treated with cold water and was filtered. For more purification, ligand was recrystallized from methanol.

L: IR spectrum $\left(\mathrm{KBr}, \mathrm{cm}^{-1}\right)$ : $3435(\mathrm{~m}), 3035(\mathrm{w}), 2927(\mathrm{w}), 2907(\mathrm{~m}), 2848(\mathrm{~s}), 1651(\mathrm{vs})$, 1595(s), 1506(s), 1459(m), 1414(m), 1373(m), 1298(m), 1283(m), 1260(w), 1230(s), 1213(s), 1152(s), 1096(m), 1019(s), 984(m), 968(m), 936(w), 874(m), 845(s), 818(m), 804(m), 780(w), 580(s), 470(m), 417(m). UV-Vis spectrum [(DMF), $\left.\lambda(\mathrm{nm})\left(\varepsilon, \mathrm{M}^{-1} \mathrm{~cm}^{-1}\right)\right]$ : 251(378570), 276(sh)(15746) and 287(sh)(11864). ${ }^{1} \mathrm{H}-\mathrm{NMR}$ spectrum (DMSO-d $\left.\mathrm{d}_{6}\right): 8.31(\mathrm{~s}$, $2 \mathrm{H}), 7.74\left(\mathrm{dt}, 4 \mathrm{H}, \mathrm{J}_{\mathrm{HH}}=6.11 \mathrm{~Hz}, \mathrm{~J}_{\mathrm{HF}}=5.98 \mathrm{~Hz}\right.$ and $\left.\mathrm{J}=2.05 \mathrm{~Hz}\right), 7.22\left(\mathrm{t}, 4 \mathrm{H}, \mathrm{J}_{\mathrm{HF}}=8.80 \mathrm{~Hz}\right.$ and $\mathrm{J}=8.75 \mathrm{~Hz}), 3.84(\mathrm{~s}, 4 \mathrm{H}) \mathrm{ppm} .{ }^{13} \mathrm{C}-\mathrm{NMR}$ spectrum $\left(\mathrm{DMSO}-\mathrm{d}_{6}\right): 163.40(\mathrm{~d}, \mathrm{~J}=985.5 \mathrm{~Hz})$, 160.51, 132.60, 129.87(d, J= 34.55 Hz), 115.50(d, J= 86.90 Hz), 60.67 ppm.

Preparation of $M L X_{2}$ complexes $\left(M=Z n(I I), C d(I I)\right.$ and $H g(I I)$, and $X=\mathrm{Cl}^{-}, \mathrm{Br}^{-}, \mathrm{I}, \mathrm{SCN}$ and $\mathrm{N}_{3}^{-}$)

A solution of $1 \mathrm{mmol}$ of ligand $(0.272 \mathrm{~g})$ in $20 \mathrm{~mL}$ of methanol or ethanol was added dropwise under stirring to the solution of $1 \mathrm{mmol}$ of $\mathrm{MX}_{2}$ in methanol $(20 \mathrm{~mL})$. The mixture was stirred for $3 \mathrm{~h}$ and complexes as a precipitate were filtered and for purification washed twice with methanol. Then complexes were dried at $\left(80-100{ }^{\circ} \mathrm{C}\right)$ under vacuum and were kept in a desiccator over silica-gel.

$\mathrm{ZnLCl}_{2}$ : IR spectrum $\left(\mathrm{KBr}, \mathrm{cm}^{-1}\right):$ 3441(m), 3061(m), 2944(m), 1647(vs), 1603(s), 1510(s), 1438(m), 1390(m), 1336(m), 1304(m), 1230(s), 1160(s), 1107(w), 1091(m), 1041(s), 1011(w), 972(m), 949(w), 936(m), 879(m), 855(s), 831(s), 794(m), 783(w), $712(\mathrm{w}), 607(\mathrm{w}), 578(\mathrm{~s}), 516(\mathrm{~s}), 492(\mathrm{~m}), 419(\mathrm{~m})$. UV-Vis spectrum $\left[\left(\mathrm{CHCl}_{3}\right), \lambda(\mathrm{nm})\left(\varepsilon, \mathrm{M}^{-1}\right.\right.$ $\left.\mathrm{cm}^{-1}\right)$ ]: 271 (33037). ${ }^{1} \mathrm{H}-\mathrm{NMR}$ spectrum $\left(\mathrm{DMSO}-\mathrm{d}_{6}\right): 8.24(\mathrm{~s}, 2 \mathrm{H}), 7.68\left(\mathrm{dt}, 4 \mathrm{H}, \mathrm{J}_{\mathrm{HH}}=6.20 \mathrm{~Hz}\right.$, $\mathrm{J}_{\mathrm{HF}}=6.12 \mathrm{~Hz}$ and $\left.\mathrm{J}=2.00 \mathrm{~Hz}\right), 7.15\left(\mathrm{t}, 4 \mathrm{H}, \mathrm{J}_{\mathrm{HF}}=8.80 \mathrm{~Hz}\right.$ and $\left.\mathrm{J}_{\mathrm{HH}}=8.80 \mathrm{~Hz}\right), 3.77(\mathrm{~s}, 4 \mathrm{H}) \mathrm{ppm}$.

${ }^{13} \mathrm{C}-\mathrm{NMR}$ spectrum (DMSO-d $\left.\mathrm{d}_{6}\right): 163.49(\mathrm{~d}, \mathrm{~J}=986.5 \mathrm{~Hz}), 160.71,132.61(\mathrm{~d}, \mathrm{~J}=9.90 \mathrm{~Hz})$, 129.99(d, J= 34.60 Hz), 115.56(d, J= 87.15 Hz), 60.69 ppm.

$\mathrm{ZnLBr}_{2}$ : IR spectrum $\left(\mathrm{KBr}, \mathrm{cm}^{-1}\right): 3435(\mathrm{~m}), 3059(\mathrm{~m}), 2941(\mathrm{~m}), 1644(\mathrm{vs}), 1603(\mathrm{~s})$, 1509(s), 1435(m), 1391(m), 1336(m), 1305(m), 1230(s), 1161(s), 1107(w), 1091(m), 1043(s), 1012(w), 970(m), 948(w), 936(m), 876(m), 853(s), 838(s), 794(m), 783(w), 712(w), 608(w), 576(s), 515(s), 494(m), 418(m). UV-Vis spectrum $\left[\left(\mathrm{CHCl}_{3}\right), \lambda(\mathrm{nm})\left(\varepsilon, \mathrm{M}^{-}\right.\right.$ $\left.{ }^{1} \mathrm{~cm}^{-1}\right)$ ]: 272 (35273). ${ }^{1} \mathrm{H}-\mathrm{NMR}$ spectrum (DMSO-d $\mathrm{d}_{6}$ ): 8.30(s, 2H), 7.73(dd, $4 \mathrm{H}, \mathrm{J}_{\mathrm{HH}}=8.28$ $\mathrm{Hz}$ and $\left.\mathrm{J}_{\mathrm{HF}}=5.80 \mathrm{~Hz}\right), 7.21\left(\mathrm{t}, 4 \mathrm{H}, \mathrm{J}_{\mathrm{HF}}=8.70 \mathrm{~Hz}\right.$ and $\left.\mathrm{J}_{\mathrm{HH}}=8.70 \mathrm{~Hz}\right), 3.83(\mathrm{~s}, 4 \mathrm{H}) \mathrm{ppm} .{ }^{13} \mathrm{C}-$ NMR spectrum (DMSO-d $\left.)_{6}\right): 163.46(\mathrm{~d}, \mathrm{~J}=986.80 \mathrm{~Hz}), 160.65,132.62(\mathrm{~d}, \mathrm{~J}=9.90 \mathrm{~Hz})$, $129.96(\mathrm{~d}, \mathrm{~J}=34.55 \mathrm{~Hz}), 115.58(\mathrm{~d}, \mathrm{~J}=86.85 \mathrm{~Hz}), 60.68 \mathrm{ppm}$. 
$\mathrm{ZnLI}_{2}$ : IR spectrum $\left(\mathrm{KBr}, \mathrm{cm}^{-1}\right)$ : 3435(m), 3057(w), 2934(w), 1639(vs), 1601(s), 1508(s), 1433(m), 1397(m), 1336(m), 1305(m), 1229(s), 1160(s), 1105(w), 1091(m), 1038(m), 981(w), 945(w), 934(w), 875(m), 851(s), 834(s), 793(m), 782(w), 710(w), 608(w), 576(s), 514(s), 493(m), 413(w). UV-Vis spectrum [( $\left.\left.\mathrm{CHCl}_{3}\right), \quad \lambda(\mathrm{nm}) \quad\left(\varepsilon, \mathrm{M}^{-1} \mathrm{~cm}^{-1}\right)\right]$ : 270(41847). ${ }^{1} \mathrm{H}-\mathrm{NMR}$ spectrum (DMSO-d $\left.\mathrm{d}_{6}\right): 8.29(\mathrm{~s}, 2 \mathrm{H}), 7.72\left(\mathrm{dt}, 4 \mathrm{H}, \mathrm{J}_{\mathrm{HH}}=6.20 \mathrm{~Hz}, \mathrm{~J}_{\mathrm{HF}}=\right.$ $6.15 \mathrm{~Hz}$ and $\mathrm{J}=2.90 \mathrm{~Hz}), 7.19\left(\mathrm{t}, 4 \mathrm{H}, \mathrm{J}_{\mathrm{HF}}=8.80 \mathrm{~Hz}\right.$ and $\left.\mathrm{J}_{\mathrm{HH}}=8.80 \mathrm{~Hz}\right), 3.81(\mathrm{~s}, 4 \mathrm{H}) \mathrm{ppm} .{ }^{13} \mathrm{C}-$ NMR spectrum $\left.(\text { DMSO-d })_{6}\right): 163.47(\mathrm{~d}, \mathrm{~J}=985.75 \mathrm{~Hz}), 160.64,132.65,130.00(\mathrm{~d}, \mathrm{~J}=34.50$ $\mathrm{Hz}), 115.62(\mathrm{~d}, \mathrm{~J}=86.95 \mathrm{~Hz}), 60.71 \mathrm{ppm}$.

$\mathrm{ZnL}(\mathrm{SCN})_{2}$ : IR spectrum $\left(\mathrm{KBr}, \mathrm{cm}^{-1}\right): 3435(\mathrm{~m}), 3073(\mathrm{w}), 2942(\mathrm{w}), 2089(\mathrm{vs}), 2068(\mathrm{vs})$, 1637(vs), 1598(s), 1508(s), 1442(m), 1402(m), 1343(m), 1305(m), 1261(w), 1235(s), 1158(s), 1107(w), 1092(m), 1037(m), 982(w), 952(m), 875(w), 835(s), 798(m), 785(w), 712(w), 598(m), 577(m), 517(s), 483(m), 419(w). UV-Vis [(DMSO), $\left.\lambda(\mathrm{nm})\left(\varepsilon, \mathrm{M}^{-1} \mathrm{~cm}^{-1}\right)\right]$ : 257(35418) and 276(sh)(29487). ${ }^{1} \mathrm{H}-\mathrm{NMR}$ spectrum (DMSO-d $\left.\mathrm{d}_{6}\right): 8.28(\mathrm{~s}, 2 \mathrm{H}), 7.72(\mathrm{dd}, 4 \mathrm{H}$, $\mathrm{J}_{\mathrm{HH}}=8.58 \mathrm{~Hz}$ and $\left.\mathrm{J}_{\mathrm{HF}}=5.75 \mathrm{~Hz}\right), 7.18\left(\mathrm{t}, 4 \mathrm{H}, \mathrm{J}_{\mathrm{HF}}=8.80 \mathrm{~Hz}\right.$ and $\left.\mathrm{J}_{\mathrm{HH}}=8.80 \mathrm{~Hz}\right), 3.82(\mathrm{~s}, 4 \mathrm{H})$ ppm. ${ }^{13} \mathrm{C}-\mathrm{NMR}$ spectrum $\left(\mathrm{DMSO}_{\mathrm{d}}\right.$ ): 163.50(d, J=986.35 Hz), 160.58, 135.45, 132.68, 129.96(d, J=34.50 Hz), 115.57(d, J=87.00 Hz), 60.75 ppm.

$\mathrm{ZnL}\left(\mathrm{N}_{3}\right)_{2}$ : IR spectrum $\left(\mathrm{KBr}, \mathrm{cm}^{-1}\right): 3375(\mathrm{~m}), 2919(\mathrm{w}), 2856(\mathrm{w}), 2065(\mathrm{vs}), 1641(\mathrm{vs})$, 1601(s), 1507(s), 1451(m), 1370(s), 1342(s), 1302(m), 1260(w), 1230(s), 1152(s), 1095(m), 1039(m), 1017(m), 985(w), 956(m), 873(w), 834(s), 795(m), 782(w), 712(w), 597(m), 576(s), 519(s), 485(w), 420(m). UV-Vis [(DMSO), $\left.\lambda(\mathrm{nm})\left(\varepsilon, \mathrm{M}^{-1} \mathrm{~cm}^{-1}\right)\right]: 258(29735)$ and 281(sh)(19564). ${ }^{1} \mathrm{H}-\mathrm{NMR}$ spectrum (DMSO-d $\left.{ }_{6}\right): 8.29(\mathrm{~s}, 2 \mathrm{H}), 7.73\left(\mathrm{dd}, 4 \mathrm{H} \mathrm{J}_{\mathrm{HH}}=8.65 \mathrm{~Hz}\right.$ and $\mathrm{J}=5.70 \mathrm{~Hz}), 7.21\left(\mathrm{t}, 4 \mathrm{H}, \mathrm{J}_{\mathrm{HF}}=8.80 \mathrm{~Hz}\right.$ and $\left.\mathrm{J}_{\mathrm{HH}}=8.85 \mathrm{~Hz}\right), .3 .83(\mathrm{~s}, 4 \mathrm{H}) \mathrm{ppm} .{ }^{13} \mathrm{C}-\mathrm{NMR}$ spectrum (DMSO-d $\left.{ }_{6}\right): 163.52(d, J=986.65 \mathrm{~Hz}), 160.68,132.38,129.99(\mathrm{~d}, \mathrm{~J}=34.55 \mathrm{~Hz})$, $112.60(\mathrm{~d}, \mathrm{~J}=87.20 \mathrm{~Hz}), 60.73 \mathrm{ppm}$.

$\mathrm{CdLI}_{2}$ : IR spectrum $\left(\mathrm{KBr}, \mathrm{cm}^{-1}\right): 3435(\mathrm{~m}), 3055(\mathrm{w}), 2936(\mathrm{w}), 1641(\mathrm{vs}), 1601(\mathrm{~s})$, 1509(s), 1338(m), 1302(m), 1259(w), 1229(s), 1158(s), 1105(w), 1092(w), 1036(m), 1011(w), 977(w), 943(w), 930(w), 872(w), 852(m), 829(s), 792(m), 779(w), 710(w), 634(w), 583(m), 571(m), 513(s), 481(m), 412(m). UV-Vis [ $\left.\left(\mathrm{CHCl}_{3}\right), \lambda(\mathrm{nm})\left(\varepsilon, \mathrm{M}^{-1} \mathrm{~cm}^{-1}\right)\right]$ : 261(52089). ${ }^{1} \mathrm{H}-\mathrm{NMR}$ spectrum (DMSO-d $\left.\mathrm{d}_{6}\right): 8.31(\mathrm{~s}, 2 \mathrm{H}), 7.75(\mathrm{~m}, 4 \mathrm{H}), 7.21\left(\mathrm{t}, 4 \mathrm{H}, \mathrm{J}_{\mathrm{HF}}=8.40\right.$ $\mathrm{Hz}$ and $\left.\mathrm{J}_{\mathrm{HH}}=8.15 \mathrm{~Hz}\right), 3.84(\mathrm{~s}, 4 \mathrm{H}) \mathrm{ppm} .{ }^{13} \mathrm{C}-\mathrm{NMR}$ spectrum (DMSO-d $\left.\mathrm{d}_{6}\right)$ : $163.42(\mathrm{~d}$, $\mathrm{J}=985.45 \mathrm{~Hz}), 160.54,132.62,129.91(\mathrm{~d}, \mathrm{~J}=34.90 \mathrm{~Hz}), 115.49(\mathrm{~d}, \mathrm{~J}=86.55 \mathrm{~Hz}), 60.67 \mathrm{ppm}$.

$\mathrm{CdL}(\mathrm{SCN})_{2}$ : IR spectrum $\left(\mathrm{KBr}, \mathrm{cm}^{-1}\right): 3435(\mathrm{~m}), 3075(\mathrm{w}), 2951(\mathrm{~m}), 2906(\mathrm{w}), 2122(\mathrm{vs})$, 2096(vs), 1647(vs), 1604(s), 1510(s), 1459(w), 1434(m), 1383(m), 1347(m), 1303(m), 1272(w), 1234(s), 1158(s), 1094(m), 1023(m), 999(s), 966(m), 941(w), 861(m), 834(s), 785(m), 712(w), 595(m), 572(s), 525(s), 464(m), 421(w). UV-Vis [(DMSO), $\left.\lambda(\mathrm{nm})\left(\varepsilon, \mathrm{M}^{-1} \mathrm{~cm}^{-1}\right)\right]$ : 258(49529) and 273(47179). ${ }^{1} \mathrm{H}-\mathrm{NMR}$ spectrum (DMSO- $\left.\mathrm{d}_{6}\right): 8.46(\mathrm{~s}, 2 \mathrm{H}), 7.86(\mathrm{~m}, 4 \mathrm{H})$,

7.28(t, $4 \mathrm{H}, \mathrm{J}_{\mathrm{HF}}=7.20 \mathrm{~Hz}$ and $\left.\mathrm{J}_{\mathrm{HH}}=8.65 \mathrm{~Hz}\right), 3.63(\mathrm{~s}, 4 \mathrm{H}) \mathrm{ppm} .{ }^{13} \mathrm{C}-\mathrm{NMR}$ spectra $\left(\right.$ DMSO- $\left.\mathrm{d}_{6}\right)$ : $163.49(\mathrm{~d}, \mathrm{~J}=931.9 \mathrm{~Hz}), 160.58,133.01,131.84,129.93(\mathrm{~d}, \mathrm{~J}=34.55 \mathrm{~Hz}), 115.52(\mathrm{~d}, \mathrm{~J}=87.10$ $\mathrm{Hz}), 60.68 \mathrm{ppm}$.

$\mathrm{HgLCl}_{2}$ : IR spectrum $\left(\mathrm{KBr}, \mathrm{cm}^{-1}\right): 3465(\mathrm{~m}), 2917(\mathrm{w}), 1637(\mathrm{vs}), 1600(\mathrm{~s}), 1507(\mathrm{~s})$, 1443(m), 1392(w), 1344(m), 1295(m), 1234(s), 1152(s), 1102(w), 1040(m), 987(w), 941(m), 855(w), 829(s), 781(w), 585(m), 512(s), 477(w), 417(w). UV-Vis [(DMSO), $\lambda(\mathrm{nm})$ $\left.\left(\varepsilon, \mathrm{M}^{-1} \mathrm{~cm}^{-1}\right)\right]: 258(67911)$ and 275(66595). ${ }^{1} \mathrm{H}-\mathrm{NMR}$ spectrum (DMSO-d $\left.\mathrm{d}_{6}\right): 8.56(\mathrm{~s}, 2 \mathrm{H})$, $7.92\left(\mathrm{t}, 4 \mathrm{H}, \mathrm{J}_{\mathrm{HH}}=8.00 \mathrm{~Hz}\right.$ and $\left.\mathrm{J}_{\mathrm{HF}}=5.85 \mathrm{~Hz}\right), 7.24\left(\mathrm{t}, 4 \mathrm{H}, \mathrm{J}_{\mathrm{HF}}=7.35 \mathrm{~Hz}\right.$ and $\left.\mathrm{J}_{\mathrm{HH}}=8.80 \mathrm{~Hz}\right)$, $3.79(\mathrm{~s}, 4 \mathrm{H})$ ppm. ${ }^{13} \mathrm{C}-\mathrm{NMR}$ spectrum $\left(\mathrm{DMSO}-\mathrm{d}_{6}\right): 163.95(\mathrm{~d}, \mathrm{~J}=992.80 \mathrm{~Hz}), 160.83$, 132.46(d, J= 10.65 Hz), 129.92(d, J= 34.30 Hz), 115.53(d, J=87.55 Hz), 60.59 ppm.

$\mathrm{HgLBr}_{2}$ : IR spectrum $\left(\mathrm{KBr}, \mathrm{cm}^{-1}\right)$ : 3442(m), 3057(w), 3037(w), 2921(m), 2894(m), 1644(vs), 1602(s), 1508(s), 1459(w), 1442(m), 1415(m), 1373(m), 1338(w), 1300(m), 1285(m), 1232(s), 1154(s), 1096(m), 1038(m), 1017(s), 972(m), 938(m), 875(m), 833(s), 
780(m), 712(w), 688(w), 605(m), 581(s), 520(s), 480(m), 421(w). UV-Vis [(DMSO), $\lambda(\mathrm{nm})$ $\left(\varepsilon, \mathrm{M}^{-1} \mathrm{~cm}^{-1}\right)$ ]: $275(60414) .{ }^{1} \mathrm{H}-\mathrm{NMR}$ spectrum (DMSO-d $\left.\mathrm{d}_{6}\right): 8.63(\mathrm{~s}, 2 \mathrm{H}), 7.97\left(\mathrm{t}, 4 \mathrm{H}, \mathrm{J}_{\mathrm{HH}}=5.90\right.$ $\mathrm{Hz}$ and $\left.\mathrm{J}_{\mathrm{HF}}=5.95 \mathrm{~Hz}\right), 7.28\left(\mathrm{dt}, 4 \mathrm{H}, \mathrm{J}_{\mathrm{HF}}=8.85 \mathrm{~Hz}, \mathrm{~J}_{\mathrm{HH}}=8.70 \mathrm{~Hz}\right.$ and $\left.\mathrm{J}=2.15 \mathrm{~Hz}\right), 3.79(\mathrm{~s}, 4 \mathrm{H})$ ppm. ${ }^{13} \mathrm{C}-\mathrm{NMR}$ spectrum (DMSO-d $\left.{ }_{6}\right): 163.98(\mathrm{~d}, \mathrm{~J}=993.6 \mathrm{~Hz}), 161.08,132.35,131.22(\mathrm{~d}, \mathrm{~J}=$ $35.55 \mathrm{~Hz}), 115.56(\mathrm{~d}, \mathrm{~J}=87.00 \mathrm{~Hz}), 60.57 \mathrm{ppm}$.

$\mathrm{HgLI}_{2}$ : IR spectrum $\left(\mathrm{KBr}, \mathrm{cm}^{-1}\right): 3435(\mathrm{~m}), 3056(\mathrm{w}), 2924(\mathrm{~m}), 2898(\mathrm{~m}), 1639(\mathrm{vs})$, 1600(s), 1508(s), 1416(w), 1387(w), 1337(m), 1300(m), 1227(s), 1156(s), 1102(w), 1082(w), 1036(m), 974(w), 940(w), 872(w), 854(m), 833(s), 790(w), 710(w), 570(m), $517(\mathrm{~s}), 470(\mathrm{w}), 414(\mathrm{~m})$. UV-Vis $\left[\left(\mathrm{CHCl}_{3}\right), \lambda(\mathrm{nm})\left(\varepsilon, \mathrm{M}^{-1} \mathrm{~cm}^{-1}\right)\right]: 253(48516)$ and $278(28685)$.

${ }^{1} \mathrm{H}-\mathrm{NMR}$ spectrum $\left(\mathrm{DMSO}_{\mathrm{d}}\right)$ : 8.62(s, 2H), 7.96(m, 4H), 7.26(m, 4H), 3.67(s, 4H) ppm.

${ }^{13} \mathrm{C}-\mathrm{NMR}$ spectrum $\left(\mathrm{DMSO}_{\mathrm{d}}\right)$ : $163.89(\mathrm{~d}, \mathrm{~J}=993.35 \mathrm{~Hz}), 161.01,132.27,129.97(\mathrm{~d}, \mathrm{~J}=$ $34.45 \mathrm{~Hz}), 115.41(\mathrm{~d}, \mathrm{~J}=87.55 \mathrm{~Hz}), 60.52 \mathrm{ppm}$.

$\mathrm{HgL}(\mathrm{SCN})_{2}$ : IR spectrum $\left(\mathrm{KBr}, \mathrm{cm}^{-1}\right): 3434(\mathrm{~s}), 3036(\mathrm{w}), 2908(\mathrm{~m}), 2849(\mathrm{~m}), 2110(\mathrm{vs})$, 1646(vs), 1601(s), 1507(s), 1460(w), 1415(m), 1374(m), 1298(m), 1229(s), 1153(s), 1094(m), 1018(s), 983(m), 937(w), 874(m), 843(s), 780(m), 714(w), 580(s), 530(s), 485(w), 418(m). UV-Vis $\left[\left(\mathrm{CHCl}_{3}\right), \lambda(\mathrm{nm})\left(\varepsilon, \mathrm{M}^{-1} \mathrm{~cm}^{-1}\right)\right]: 252(64099)$ and 270(42722). ${ }^{1} \mathrm{H}-\mathrm{NMR}$ spectrum $\left(\right.$ DMSO-d $\left._{6}\right): 8.31(\mathrm{~s}, 2 \mathrm{H}), 7.75(\mathrm{bs}, 4 \mathrm{H}), 7.21(\mathrm{bs}, 4 \mathrm{H}), 3.84(\mathrm{~s}, 4 \mathrm{H}) \mathrm{ppm} .{ }^{13} \mathrm{C}-\mathrm{NMR}$ spectrum (DMSO-d $\left.{ }_{6}\right): 163.45(\mathrm{~d}, \mathrm{~J}=986.10 \mathrm{~Hz}), 160.59,132.60,131.75,129.90(\mathrm{~d}, \mathrm{~J}=34.65$ $\mathrm{Hz}), 115.51(\mathrm{~d}, \mathrm{~J}=86.85 \mathrm{~Hz}), 60.69 \mathrm{ppm}$.

$\mathrm{HgL}\left(\mathrm{N}_{3}\right)_{2}$ : IR spectrum $\left(\mathrm{KBr}, \mathrm{cm}^{-1}\right): 3435(\mathrm{~m}), 3035(\mathrm{w}), 2921(\mathrm{w}), 2064(\mathrm{vs}), 2023(\mathrm{vs})$, 1648(vs), 1601(s), 1508(s), 1443(w), 1361(s), 1299(m), 1232(s), 1154(m), 1098(w), 1039(m), 976(m), 946(w), 833(s), 786(m), 713(w), 580(s), 512(m), 487(w), 407(m). UV-Vis [(DMSO), $\left.\lambda(\mathrm{nm})\left(\varepsilon, \mathrm{M}^{-1} \mathrm{~cm}^{-1}\right)\right]: 258(48161) .{ }^{1} \mathrm{H}-\mathrm{NMR}$ spectrum $\left(\mathrm{DMSO}-\mathrm{d}_{6}\right): 8.58(\mathrm{~s}, 2 \mathrm{H})$, 7.90(bs, $4 \mathrm{H}), 7.31(\mathrm{bs}, 4 \mathrm{H}), 3.70(\mathrm{bs}, 4 \mathrm{H}) \mathrm{ppm} .{ }^{13} \mathrm{C}-\mathrm{NMR}$ spectrum $\left(\mathrm{DMSO}-\mathrm{d}_{6}\right): 163.90(\mathrm{~d}$, $\mathrm{J}=992.10 \mathrm{~Hz}), 160.61,132.65,129.93(\mathrm{~d}, \mathrm{~J}=34.55 \mathrm{~Hz}), 115.67(\mathrm{~d}, \mathrm{~J}=86.95 \mathrm{~Hz}), 60.66 \mathrm{ppm}$.

\section{Results and Discussion}

Physical data

The new Schiff base ligand (L) was prepare with the condensation reaction between ethylendiamine and 4-florobenzaldehyde. In continue, the reaction of bidentate Schiff base ligand $(\mathrm{L})$ with $\mathrm{MX}_{2}$ salts $(\mathrm{X}=$ chloride, bromide and iodide thiocyanate and azide, $\mathrm{M}=$ zinc and mercury and cadmium) in a equimolar ratio give complexes with general formula $\mathrm{MLX}_{2}$. Elemental analyses and other physical properties of the ligands and their complexes are summarized in Table 1. Elemental analysis are confirmed the stoichiometry of complexes.

The molar conductivity of complexes in chloroform or DMSO as solvent $\left(1 \times 10^{-3} \mathrm{M}\right)$ was measured at room temperature. The low molar conductivity for complexes shows them to be non-electrolytes ${ }^{19-21}$.

\section{IR spectra}

The infrared spectra of ligand and its complexes were recorded in the region $4000-400 \mathrm{~cm}^{-1}$. The most characteristic absorptions of the Schiff base ligand and its complexes are presented in experimental section. The absence of symmetric and asymmetric vibration related to ($\mathrm{NH}_{2}$ ) of amine and carbonyl stretching of aldehyde in the IR spectrum of ligand and appearance a new strong peak at $1651 \mathrm{~cm}^{-1}$ suggested that the amino and aldehyde functional groups have been converted to iminic group $(\mathrm{C}=\mathrm{N})$ as a new bound. IR spectra of the complexes showed obviously change in the location of absorbance band especially for $v(\mathrm{C}=\mathrm{N})$ indicated that the Schiff base was coordinated to the metals atom. The band appearing at $1651 \mathrm{~cm}^{-1}$ due to the azomethine group $(\mathrm{C}=\mathrm{N})^{22-24}$ was shifted to lower frequency by $4-14 \mathrm{~cm}^{-1}$ indicating participation of the azomethine nitrogen in the complexation. Schiff base ligand spectrum showed the stretching frequencies at 3035, (2927 
and 2907) and $2848 \mathrm{~cm}^{-1}$ assigned to $\mathrm{C}-\mathrm{H}$ of aromatic, aliphatic and iminic groups respectively. These bonds are shifted to higher frequency after its coordination to metal ions. The absorption band assigned to $\mathrm{C}=\mathrm{C}$ bounds appeared at $1595 \mathrm{~cm}^{-1}$ that shifted to high frequency by $3-9 \mathrm{~cm}^{-1}$ after complexation. The stretching frequency at $1230 \mathrm{~cm}^{-1} \mathrm{can}$ be attributed to the $v(\mathrm{C}-\mathrm{F})$ smoothly affected by coordination of the ligand. The strong out of plane bending vibration of the aromatic $\mathrm{C}-\mathrm{H}$ is present $\mathrm{t}^{25}$ at $845 \mathrm{~cm}^{-1}$. This band is shifted to lower frequency by $2-16 \mathrm{~cm}^{-1}$ after binding of ligand to metal. Furthermore conclusive evidence that confirmed coordination of Schiff bases with the metal ions appearance of weak low-frequency new bands at 512-530 $\mathrm{cm}^{-1}$ assigned to the metal-nitrogen $v(\mathrm{M}-\mathrm{N})^{26-27}$. The absorption at 2065 $\mathrm{cm}^{-1}$ in $\mathrm{ZnL}\left(\mathrm{N}_{3}\right)_{2}$ and the absorptions at 2064 and $2023 \mathrm{~cm}^{-1}$ in $\operatorname{HgL}\left(\mathrm{N}_{3}\right)_{2}$ is assigned to coordinated $\mathrm{N}_{3}^{-28}$ and the absorption frequencies at $2068 \mathrm{~cm}^{-1}$ in $\mathrm{ZnL}(\mathrm{NCS})_{2}$ is assigned to Ncoordinated SCN, the absorption at $2110 \mathrm{~cm}^{-1}$ in $\mathrm{HgL}(\mathrm{SCN})_{2}$ and at $2122-2096 \mathrm{~cm}^{-1}$ in $\mathrm{CdL}(\mathrm{SCN})_{2}$ are assigned to $\mathrm{S}$-coordinated coordinated $\mathrm{SCN}^{-29-32}$. This observation for azide and thiocynate complexes confirms well coordination of these anions (and somewhat halide ions in other complexes) as well as Schiff base ligand to metal centers.

Table 1. Elemental analysis, color, \%yield and molar conductivity of the ligand and its complexes.

\begin{tabular}{|c|c|c|c|c|c|c|c|}
\hline \multirow[b]{2}{*}{ Entry } & \multirow[b]{2}{*}{ Compound } & \multirow{2}{*}{$\begin{array}{c}\Lambda \mathrm{M} \\
\mathrm{cm}^{2} \Omega^{-1} \mathrm{M}^{-1}\end{array}$} & \multicolumn{3}{|c|}{ Found (Calcd.) \% } & \multirow{2}{*}{ Yield, \% } & \multirow{2}{*}{ Color } \\
\hline & & & $\mathrm{H}$ & $\mathrm{N}$ & $\mathrm{C}$ & & \\
\hline 1 & Ligand & - & $\begin{array}{c}5.3 \\
(5.18)\end{array}$ & $\begin{array}{c}10.4 \\
(10.29)\end{array}$ & $\begin{array}{c}70.3 \\
(70.58)\end{array}$ & 81 & White \\
\hline 2 & $\mathrm{ZnLCl}_{2}$ & $0.04^{\mathrm{a}}$ & $\begin{array}{c}3.5 \\
(3.45)\end{array}$ & $\begin{array}{c}6.9 \\
(6.86)\end{array}$ & $\begin{array}{c}46.9 \\
(47.03)\end{array}$ & 83 & White \\
\hline 3 & $\mathrm{ZnLBr}_{2}$ & $0.074^{\mathrm{a}}$ & - & - & - & 79 & White \\
\hline 4 & $\mathrm{ZnLI}_{2}$ & $0.098^{\mathrm{a}}$ & $\begin{array}{c}2.2 \\
(2.39)\end{array}$ & $\begin{array}{c}4.9 \\
(4.74)\end{array}$ & $\begin{array}{c}31.9 \\
(32.49)\end{array}$ & 85 & White \\
\hline 5 & $\mathrm{ZnL}(\mathrm{SCN})_{2}$ & $62.17^{\mathrm{b}}$ & - & - & - & 69 & White \\
\hline 6 & $\mathrm{ZnL}\left(\mathrm{N}_{3}\right)_{2}$ & $35.46^{\mathrm{b}}$ & $\begin{array}{c}3.2 \\
(3.35)\end{array}$ & $\begin{array}{c}27.1 \\
(26.57\end{array}$ & $\begin{array}{c}45.1 \\
(45.57)\end{array}$ & 72 & cream \\
\hline 7 & $\mathrm{CdLI}_{2}$ & $0.186^{\mathrm{a}}$ & $\begin{array}{c}2.33 \\
(2.21)\end{array}$ & $\begin{array}{c}4.27 \\
(4.39)\end{array}$ & $\begin{array}{c}29.97 \\
(30.10)\end{array}$ & 78 & White \\
\hline 8 & $\mathrm{CdL}(\mathrm{SCN})_{2}$ & $76.28^{\mathrm{b}}$ & - & - & - & 80 & White \\
\hline 9 & $\mathrm{HgLCl}_{2}$ & $4.63^{\mathrm{b}}$ & $\begin{array}{c}2.40 \\
(2.59)\end{array}$ & $\begin{array}{c}5.27 \\
(5.15)\end{array}$ & $\begin{array}{c}35.12 \\
(35.34)\end{array}$ & & White \\
\hline 10 & $\mathrm{HgLBr}_{2}$ & $14.19^{\mathrm{b}}$ & - & - & - & 83 & cream \\
\hline 11 & $\mathrm{HgLI}_{2}$ & $2.40^{\mathrm{b}}$ & $\begin{array}{c}2.1 \\
(1.94)\end{array}$ & $\begin{array}{c}3.9 \\
(3.85)\end{array}$ & $\begin{array}{c}26.7 \\
(26.44)\end{array}$ & 79 & cream \\
\hline 12 & $\mathrm{HgL}(\mathrm{SCN})_{2}$ & $0.412^{\mathrm{a}}$ & $\begin{array}{c}2.3 \\
(2.40)\end{array}$ & $\begin{array}{c}9.7 \\
(9.51)\end{array}$ & $\begin{array}{c}36.3 \\
(36.70)\end{array}$ & 70 & Pale Yellow \\
\hline 13 & $\operatorname{HgL}\left(\mathrm{N}_{3}\right)_{2}$ & $26.96^{\mathrm{b}}$ & - & - & - & 68 & White \\
\hline
\end{tabular}

$a=$ the solvent is $\mathrm{CHCl}_{3}, b=$ the solvent is DMSO.

Electronic spectra

Electronic spectra of the ligand and its complexes were recorded in DMF and or chloroform at room temperature as can see in experimental section. In the spectrum of ligand, an independent absorption band appeared and two shoulder bands appeared at 251, 276 and 287 $\mathrm{nm}$ regions that first two cases may be due to $\Omega$ - ${ }^{*}$ transition of aromatic rings and the third may be related to azomethine group. In the electronic spectra of most of complexes(entries 2,3,4,7 10 and 13), the bands assigned to aromatic rings and azomethine group are merged 
together and shifted to lower energies after coordination. In zinc thiocyanate and azide, mercury bromide, iodide and thicyanate complexes, the first band of ligand shift to higher wavelengths and a strong shoulder is appeared at 276 and $281 \mathrm{~nm}$ after coordination. Finally in cadmium thiocyanate and mercury chloride complexes two independent strong bands were detectable for $\Omega \Omega^{*}$ transition of aromatic rings and azomethine group of ligand due to coordination. The $d-d$ transition bands for complexes of these transition metals due to $d^{10}$ electron configuration won't be observed. Though metal to ligand charge transfer are predictable for this type of complexes but these transition were not observed.

\section{${ }^{1} \mathrm{H}$ and ${ }^{13} \mathrm{C}$ NMR spectra}

The results data of NMR spectra of the ligand and its metal complexes have been entered in experimental section. ${ }^{1} \mathrm{H}$ and ${ }^{13} \mathrm{C}$ NMR spectra were recorded at $500 \mathrm{MHz}$, using DMSO as solvent. ${ }^{1} \mathrm{HNMR}$ and ${ }^{13} \mathrm{CNMR}$ of ligand are depicted in Figure 2. Studies of ${ }^{1} \mathrm{H}$ and ${ }^{13} \mathrm{C}$ NMR spectra exhibit that the data have excellent correlation with pseudo-tetrahedral structure that proposed before for complexes. As a functional group signal, resonance of azomethine proton $\left(\mathrm{H}_{\mathrm{b}}\right.$ and $\left.\mathrm{H}_{\mathrm{b}^{\prime}}\right)$ appeared at $8.31 \mathrm{ppm}^{22}$. These signals are red shifted to 8.46-8.63 ppm with respect to TMS for entries $8,9,10,11$ and 13 or shifted to down filed 8.24-8.30 ppm for entries 2, 3, 4, 5 and 6 and unchanged in spectra of entries 7 and 12, suggesting coordination by the azomethine nitrogens to metal ion. In the spectrum of ligand $\mathrm{H}_{\mathrm{d}, \mathrm{d}^{\prime}}$ appeared at $7.74 \mathrm{ppm}$ as a doublet of triplet due to coupling with $\mathrm{H}_{\mathrm{e}, \mathrm{e}^{\prime}}$ and fluorine atom at benzene ring with coupling constants of $6.11,5.98$ and $2.05 \mathrm{~Hz}$. In the spectra of complexes, the signals of $\mathrm{H}_{\mathrm{d}, \mathrm{d}^{\prime}}$ have shown a change in location, so that shifted to up fields (entries 7-13) or down fields (entries 2-6). Also the type of splitting of this signal changed due to coordination of ligand and appeared as doublet of doublet for entries 3,5 and 6; as triplet for entries 9 and 10, as multiple for entries 7 and 8 and as broad singlet for entries 12 and $13 . \mathrm{H}_{\mathrm{e}, \mathrm{e}^{\prime}}$ due to coupling whit $\mathrm{H}_{\mathrm{d}, \mathrm{d}^{\prime}}$ and then fluorine atom are observed at $7.22 \mathrm{ppm}$ as a triplet signal with coupling constants of 8.70 and $8.75 \mathrm{~Hz}$. In the spectra of complexes, the signals of $\mathrm{H}_{\mathrm{e}, \mathrm{e}^{\prime}}$ are almost unchanged or shifted to upfields (entries 2, 4 and 5) or down fielded (entries 8-11 and 13). On the other hand, in the spectra of $\mathrm{HgLBr}_{2}$ and $\mathrm{HgLI}_{2}$, these signals appeared as doublet of triplet and multiple signals respectively. For $\operatorname{HgL}(\mathrm{SCN})_{2}$ and $\operatorname{HgL}\left(\mathrm{N}_{3}\right)_{2}$ these signals are seen as broad singlet that these chemical shifts and signal shapes confirm coordination of ligand to metal centers. The signal of $\mathrm{H}_{\mathrm{a}, \mathrm{a}}$ protons in the ligand are exhibited as a singlet at $3.84 \mathrm{ppm}$ that are appeared as singlet in all complexes but are shifted to down fields after coordination.

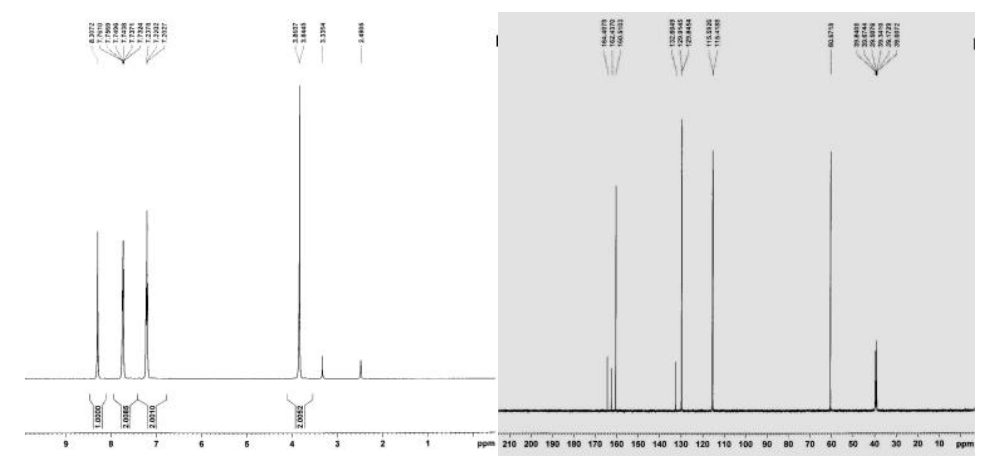

Figure 1. ${ }^{1} \mathrm{HNMR}$ and ${ }^{13} \mathrm{CNMR}$ of ligand.

In the ${ }^{13} \mathrm{C}$ NMR spectrum of the ligand, two azomethine carbons $\mathrm{C}\left(5,5^{\prime}\right)$ resonances are observed as a single peak at $160.51 \mathrm{ppm}^{16-18}$. These peaks are shifted to up field in all complexes, suggesting well coordination of the azomethine nitrogen to metal ion. Also, the 
${ }^{13} \mathrm{C}$ NMR spectrum of the ligand showed a doublet peak at $163.40 \mathrm{ppm}$ for $\mathrm{C}\left(1,1^{\prime}\right)$ carbons due to coupling with fluorine atom with $\mathrm{J}=985.50 \mathrm{~Hz}$ that shifted to lower energies after coordination. $\mathrm{C}\left(2,2^{\prime}\right)$ and $\mathrm{C}\left(3,3^{\prime}\right)$ also are effected with fluorine atom and exhibit doublet peak at 115.50 and $129.87 \mathrm{ppm}$ with coupling constants of 34.55 and $86.90 \mathrm{~Hz}$. After coordination, these peaks are stayed as doublet but with a smoothly change in their chemical shifts. A singlet peak at 132.60 and $60.67 \mathrm{ppm}$ is assigned to $C\left(4,4^{\prime}\right)$ and $C\left(6,6^{\prime}\right)$ respectively. The peaks of $\mathrm{C}\left(4,4^{\prime}\right)$ is stayed singlet in all complexes except for entries 2,3 and 9 that were transformed to doublet signals due to the coupling effect of fluorine atom. The signals related to $\mathrm{C}\left(6,6^{\prime}\right)$ are being almost unchanged in all complexes. The carbon of thiocyanate group in $\mathrm{ZnL}(\mathrm{NCS})_{2}, \mathrm{CdL}(\mathrm{SCN})_{2}$ and $\mathrm{HgL}(\mathrm{SCN})_{2}$ are found at $135.45,131.84$ and $131.75 \mathrm{ppm}$ respectively.

In final, based on the current evidences and according to previous report on this type of ligands ${ }^{4,7}$, the suggested structure for the complexes is pseudo-tetrahedral as drawn in Scheme 1 .

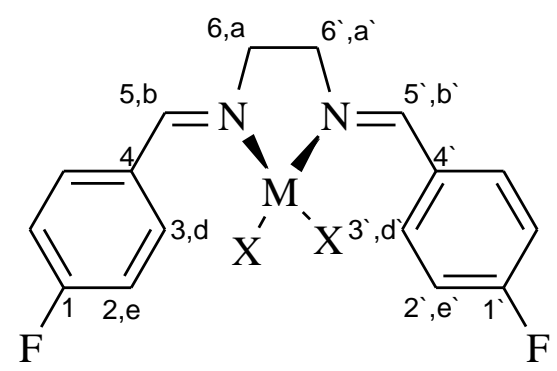

Scheme 1. Structure of complexes.

\section{Thermal investigation of Schiff base complexes}

Thermal behavior (TG/DTG) of compounds was studied on PL-1500 TG instrument from room temperature to $600{ }^{\circ} \mathrm{C}$ at the heating rates of 10 degree per minute under oxygen atmosphere. The mass loss versus temperature data of the complexes extracted from the plots are seen in Table 2. Thermogravimetric investigations of the complexes indicate some information about the thermal stability of them. Complexes lose 81.2$100 \%$ of their weight during room temperature to $600{ }^{\circ} \mathrm{C}$. The mass loss under $100{ }^{\circ} \mathrm{C}$ for some compounds indicates existence of a few lattice water molecules $(6.99,6.8,3.4$, $2.3 \%$ for Entries of 5-8 respectively). In other complexes weight loss was not observed until $200{ }^{\circ} \mathrm{C}$ indicating no water molecule (as lattice water or coordinated) in the compounds.

The thermodynamic activation parameters of decomposition processes of complexes including Arrhenius constant $(\mathrm{A})$, activation energy ( $\left.\mathrm{E}^{*}\right)$, enthalpy $\left(\Delta \mathrm{H}^{*}\right)$, entropy $\left(\Delta \mathrm{S}_{*}\right)$ and Gibbs free energy of decomposition step $\left(\Delta \mathrm{G}^{*}\right)$ are evaluated based on plots using CoatsRedfern relation ${ }^{31}$.

The calculated data are collected in Table 3. The activation energies of decomposition are found to be in the range of $8-127 \mathrm{~kJ} / \mathrm{mol}$. This range of values of the activation energies indicates relative thermal stability of the complexes. $\Delta S^{*}$ values are negative in most of investigated steps that states decomposition reactions proceed with lower rates than normal ones. $\Delta \mathrm{H}^{*}$ and $\Delta G^{*}$ values are positive and placed at ranges of $4.38-124 \mathrm{~kJ} / \mathrm{mol}$ and $106-258 \mathrm{~kJ} / \mathrm{mol}$ respectively. 
Table 2. Thermal analysis data including temperature range, mass loss and proposed residue.

\begin{tabular}{|c|c|c|c|}
\hline Entry & Complex & Temperature step, ${ }^{\circ} \mathrm{C}$ & $\sim$ Mass loss, $\%$ \\
\hline \multirow[t]{3}{*}{1} & $\mathrm{ZnLCl}_{2}$ & $200-325$ & 53.1 \\
\hline & & $325-385$ & 14.9 \\
\hline & & $385-700$ & 24.1 \\
\hline \multirow[t]{2}{*}{2} & $\mathrm{ZnLBr}_{2}$ & $200-340$ & 40.2 \\
\hline & & $340-600$ & 59.8 \\
\hline \multirow[t]{3}{*}{3} & $\mathrm{ZnLI}_{2}$ & $200-340$ & 54.5 \\
\hline & & $340-440$ & 43.5 \\
\hline & & $440-600$ & 2 \\
\hline \multirow[t]{3}{*}{4} & $\mathrm{CdLI}_{2}$ & $200-240$ & 8.7 \\
\hline & & $240-405$ & 18 \\
\hline & & $405-600$ & 54.7 \\
\hline \multirow[t]{3}{*}{5} & $\mathrm{HgLCl}_{2} \cdot \mathrm{nH}_{2} \mathrm{O}$ & $25-100$ & 6.99 \\
\hline & & $200-265$ & 36.3 \\
\hline & & $265-600$ & 56.7 \\
\hline \multirow[t]{3}{*}{6} & $\mathrm{HgLBr}_{2} \cdot \mathrm{nH}_{2} \mathrm{O}$ & $25-100$ & 6.8 \\
\hline & & $200-270$ & 36.6 \\
\hline & & $270-600$ & 56.6 \\
\hline \multirow[t]{3}{*}{7} & $\mathrm{HgLI}_{2} \cdot \mathrm{nH}_{2} \mathrm{O}$ & $25-100$ & 3.4 \\
\hline & & $180-240$ & 34.4 \\
\hline & & $240-500$ & 62.2 \\
\hline \multirow[t]{4}{*}{8} & $\mathrm{HgL}(\mathrm{SCN})_{2} \cdot \mathrm{nH}_{2} \mathrm{O}$ & $25-100$ & 2.3 \\
\hline & & $200-330$ & 72.2 \\
\hline & & $300-500$ & 6.2 \\
\hline & & $500-700$ & 19.3 \\
\hline \multirow[t]{4}{*}{9} & $\operatorname{HgL}\left(\mathrm{N}_{3}\right)_{2}$ & $200-225$ & 42.5 \\
\hline & & $225-230$ & 29 \\
\hline & & $230-400$ & 22.1 \\
\hline & & $400-550$ & 6.4 \\
\hline
\end{tabular}

Table 3. Thermodynamic activation parameters of decomposition processes of complexes.

\begin{tabular}{|c|c|c|c|c|c|c|}
\hline Complex & $\begin{array}{c}\text { Temperature } \\
\text { range }^{\mathrm{a},}{ }^{\circ} \mathrm{C}\end{array}$ & $\begin{array}{c}E^{*} \\
\left(\mathrm{kJmol}^{-1}\right) \\
\end{array}$ & $A\left(\mathrm{~s}^{-1}\right)$ & $\begin{array}{c}\Delta S^{*} \\
\left(\mathrm{kJmol}^{-1}\right)\end{array}$ & $\begin{array}{c}\Delta H^{*} \\
\left(\mathrm{kJmol}^{-1}\right)\end{array}$ & $\begin{array}{c}\Delta G^{*} \\
\left(\mathrm{kJmol}^{-1}\right)\end{array}$ \\
\hline \multirow[t]{3}{*}{$\mathrm{ZnLCl}_{2}$} & $230-325$ & $1.04 * 10^{2}$ & $2.43 * 10^{7}$ & $-1.09 * 10^{2}$ & $9.89 * 10$ & $1.60 * 10^{2}$ \\
\hline & $325-385$ & $3.37 * 10$ & 1.60 & $-2.47 * 10^{2}$ & $2.83 * 10$ & $1.88 * 10^{2}$ \\
\hline & $400-605$ & $1.40 * 10$ & $8.31 * 10^{2}$ & $-2.74 * 10^{2}$ & 7.37 & $2.24 * 10^{2}$ \\
\hline \multirow[t]{2}{*}{$\mathrm{ZnLBr}_{2}$} & $230-325$ & $4.21 * 10$ & $1.50 * 10$ & $-2.28 * 10^{2}$ & $3.72 * 10$ & $1.71 * 10^{2}$ \\
\hline & $340-520$ & $2.24 * 10$ & $4.84 * 10^{-2}$ & $-2.78 * 10^{2}$ & $1.60 * 10$ & $2.28 * 10^{2}$ \\
\hline \multirow[t]{3}{*}{$\mathrm{ZnLI}_{2}$} & $255-340$ & $1.08 * 10^{2}$ & $1.95 * 10^{7}$ & $-1.11 * 10^{2}$ & $1.03 * 10^{2}$ & $1.66 * 10^{2}$ \\
\hline & $355-400$ & $1.17 * 10^{2}$ & $1.43 * 10^{7}$ & $-1.15^{*} 10^{2}$ & $1.12 * 10^{2}$ & $1.87 * 10^{2}$ \\
\hline & $405-465$ & $4.24 * 10$ & 4.38 & $-2.40 * 10^{2}$ & $3.64 * 10$ & $2.09 * 10^{2}$ \\
\hline \multirow[t]{3}{*}{$\mathrm{CdLI}_{2}$} & $200-240$ & $9.20 * 10$ & $9.98 * 10^{7}$ & $-9.57 * 10$ & $8.81 * 10$ & $1.34 * 10^{2}$ \\
\hline & $260-405$ & $3.27 * 10$ & $9.40 * 10^{-1}$ & $-2.52 * 10^{2}$ & $2.73 * 10$ & $1.90 * 10^{2}$ \\
\hline & $415-555$ & $6.36 * 10$ & $4.23 * 10$ & $-2.22 * 10^{2}$ & $5.72 * 10$ & $2.29 * 10^{2}$ \\
\hline \multirow[t]{3}{*}{$\mathrm{HgLCl}_{2}$} & $90-175$ & 8.00 & $7.77 * 10^{-2}$ & $-2.69 * 10^{2}$ & 4.38 & $1.22 * 10^{2}$ \\
\hline & $175-250$ & $5.93 * 10$ & $5.77 * 10^{3}$ & $-1.77 * 10^{2}$ & $5.51 * 10$ & $1.44^{*} 10^{2}$ \\
\hline & $275-370$ & $4.74 * 10$ & $4.38 * 10$ & $-2.19 * 10^{2}$ & $4.21 * 10$ & $\begin{array}{c}1.75 * 10^{2} \\
\text { Condt } \ldots\end{array}$ \\
\hline
\end{tabular}




\begin{tabular}{|c|c|c|c|c|c|c|}
\hline \multirow[t]{3}{*}{$\mathrm{HgLBr}_{2}$} & $60-165$ & $1.10 * 10$ & $7.55 * 10^{-2}$ & $-2.69 * 10^{2}$ & 7.73 & $1.14 * 10^{2}$ \\
\hline & $195-260$ & $7.02 * 10$ & $7.98 * 10^{4}$ & $-1.56 * 10^{2}$ & $6.60 * 10$ & $1.45 * 10^{2}$ \\
\hline & $280-360$ & $4.32 * 10$ & $1.77 * 10$ & $-2.27 * 10^{2}$ & $3.82 * 10$ & $1.75 * 10^{2}$ \\
\hline \multirow[t]{3}{*}{$\mathrm{HgLI}_{2}$} & $70-145$ & $2.73 * 10$ & $2.34 * 10$ & $-2.21 * 10^{2}$ & $2.41 * 10$ & $1.09 * 10^{2}$ \\
\hline & $185-230$ & $1.17 * 10^{2}$ & $3.50 * 10^{10}$ & $-4.72 * 10$ & $1.13 * 10^{2}$ & $1.36 * 10^{2}$ \\
\hline & $230-325$ & $5.03 * 10$ & $1.50 * 10^{2}$ & $-2.09 * 10^{2}$ & $4.56 * 10$ & $1.64 * 10^{2}$ \\
\hline \multirow{3}{*}{$\mathrm{HgL}(\mathrm{SCN})_{2}$} & $110-215$ & $6.73 * 10$ & $2.40 * 10^{5}$ & $-1.46 * 10^{2}$ & $6.34 * 10$ & $1.31 * 10^{2}$ \\
\hline & $280-500$ & $1.62 * 10$ & $6.96 * 10^{-2}$ & $-2.73 * 10^{2}$ & $1.11 * 10$ & $1.77 * 10^{2}$ \\
\hline & $510-635$ & $2.99 * 10$ & $1.39 * 10^{-1}$ & $-2.70 * 10^{2}$ & $2.26 * 10$ & $2.58 * 10^{2}$ \\
\hline \multirow{6}{*}{$\operatorname{HgL}\left(\mathrm{N}_{3}\right)_{2}$} & $70-120$ & $3.26 * 10$ & $1.83 * 10^{2}$ & $-2.04 * 10^{2}$ & $2.95 * 10$ & $1.06 * 10^{2}$ \\
\hline & $145-175$ & $1.21 * 10^{2}$ & $2.34 * 10^{12}$ & $-1.14 * 10$ & $1.17 * 10^{2}$ & $1.22 * 10^{2}$ \\
\hline & $180-205$ & $1.27 * 10^{2}$ & $2.51 * 10^{12}$ & $-1.13 * 10$ & $1.24 * 10^{2}$ & $1.29 * 10^{2}$ \\
\hline & $205-250$ & $1.02 * 10^{2}$ & $3.38 * 10^{8}$ & $-8.60 * 10$ & $9.78 * 10$ & $1.41 * 10^{2}$ \\
\hline & $315-425$ & $1.98 * 10$ & $1.56 * 10^{-1}$ & $-2.67 * 10^{2}$ & $1.45 * 10$ & $1.85 * 10^{2}$ \\
\hline & $425-525$ & $1.38 * 10$ & $1.48 * 10^{-1}$ & $-2.69 * 10^{2}$ & 7.25 & $2.18 * 10^{2}$ \\
\hline
\end{tabular}

${ }^{a}$ refers to selected decomposition temperature range.

\section{Acknowledgment}

Partial support of this work by Yasouj University is acknowledged.

\section{References}

1. Schiff H, Ann Chim., 1864, 131, 118.

2. Wu KY, Hsieh CC and Horng YC, J Organomet Chem., 2009, 694(13), 2085-2091.

3. Zhang J, Pan F, Cheng H and Du W, Russian J Coord Chem., 2010, 36(7), 514-519.

4. Wang W, Li J, Du GX and Feng Z X, Acta Cryst., 2004, E60(3), m334-m335.

5. Habibi M H, Lalegani A, Mokhtari R and Suzuki T, Acta Cryst E., 2007, E63, m2479-m2480.

6. Habibi M H, Mokhtari R, Harrington R W and Clegg W, Acta Cryst., 2007, E63, m2304-m2305.

7. Habibi MH, Montazerozohori M, Lalegani A, Harrington RW and Clegg W, Anal Sci $X$-ray Structure Anal., 2007, (23), X51-X52.

8. Gupta K C and Sutar A K, Coord Chem Rev., 2008, 252, 1420-1450.

9. Cozzi P G, Chem Soc Rev., 2004, 33, 410-421.

10. Di Bella S, Fragala I, Ledoux I and Marks T J, J Am Chem Soc., 1995, 117, 9481-9485.

11. Hwang KY, Lee M H, Jang H, Sung Y, Lee J S, Kim S H and Do Y K, Dalton Trans., 2008, 1818-1820.

12. Palys B J, Bukowska J and Jackowska K, J Electroanal Chem., 1997, 428, 19.

13. Shabani F, Saghatforoush LA and Ghammamy S, Bull Chem Soc Ethiop., 2010, 24(2), 193-199.

14. Kumar K S, Ganguly S, Veerasamy R and De Clercq E, Europ J Med Chem., 2010, 45, 5474-5479.

15. Raman N, Sakthivel A and Rajasekaran K, Mycobiology., 2007, 35(3), 150-153.

16. Montazerozohori M and Musavi S A, J Coord Chem., 2008, 61, 3934-3942.

17. Montazerozohori M Joohari S and Musavi S A, J Coord Chem., 2009, 62, 1285-1292.

18. Montazerozohori M Joohari S and Musavi S A, Spectrochim Acta A, 2009, 73(2), 231-237.

19. Geary W, J Coord Chem Rev., 1971, 7, 81. 
20. Sönmez, M, Turk J Chem, 2001, 25, 181-185.

21. El-ajaily M M, El-Ferjani R M and Maihub A A Jordan J Chem., 2007, 2, 287-296.

22. Dehghanpour S; Mahmoudkhani AH, Amirnasr AM, Struc Chem., 2006, 17, 255 and references therein.

23. Zhu D, Su Z, Mu Z, Qiu Y and Wang Y, J Coord Chem., 2006, 59, 409.

24. Prakash PD and Patel M N Synth React Inorg Met Org Chem., 2002, 32, 753.

25. Pavia D L, Lampman G M and Kriz G S, Introduction to Spectroscopy, Edn. 2000, 3.

26. Blower P J, Transition Met Chem., 1998, 23,109.

27. Chohan ZH and Pervez H H, Synth React Inorg Met-Org Chem., 1993, 23, 1061.

28. Das D, Chand B G, Sarker K K, Dind J and Sinha C, Polyhedron, 2006, 25, 2333-2340.

29. Samanta B, Chakraborty J, Choudhury C R, Dey S K, Dey D K, Batten S R, Jensen P, Yap G P A and Mitra S, Struct Chem., 2007, 18, 33.

30. Zhang C, Tian G and Liu B, Transition MetChem., 2000, 25, 377.

31. Sen S, Talukder P, Rosair G, Mitra S, Struct Chem., 2005, 16, 605.

32. Sabatini B A, Inorg Chem., 1966, 5(6), 1025-1028. 


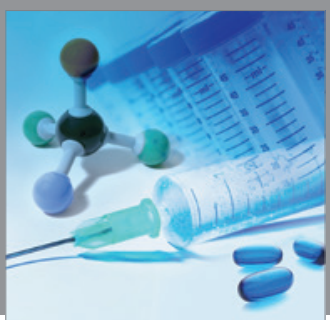

International Journal of

Medicinal Chemistry

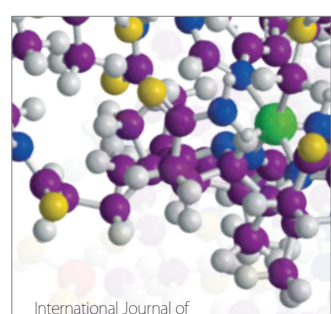

Carbohydrate Chemistry

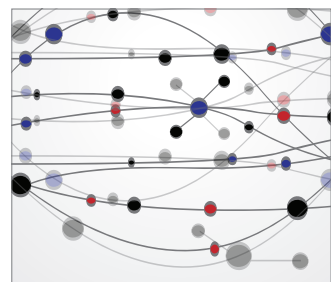

The Scientific World Journal
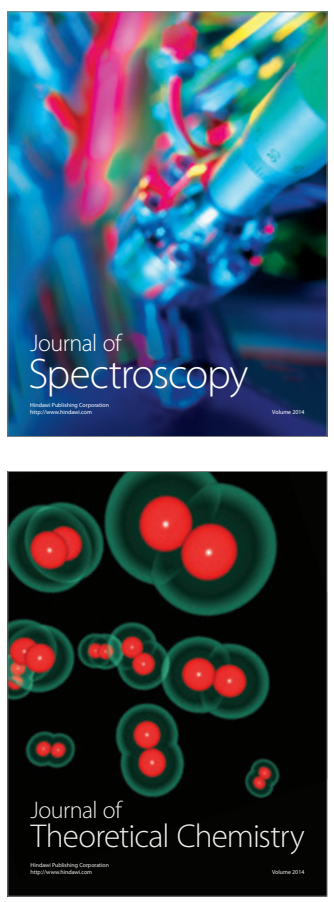
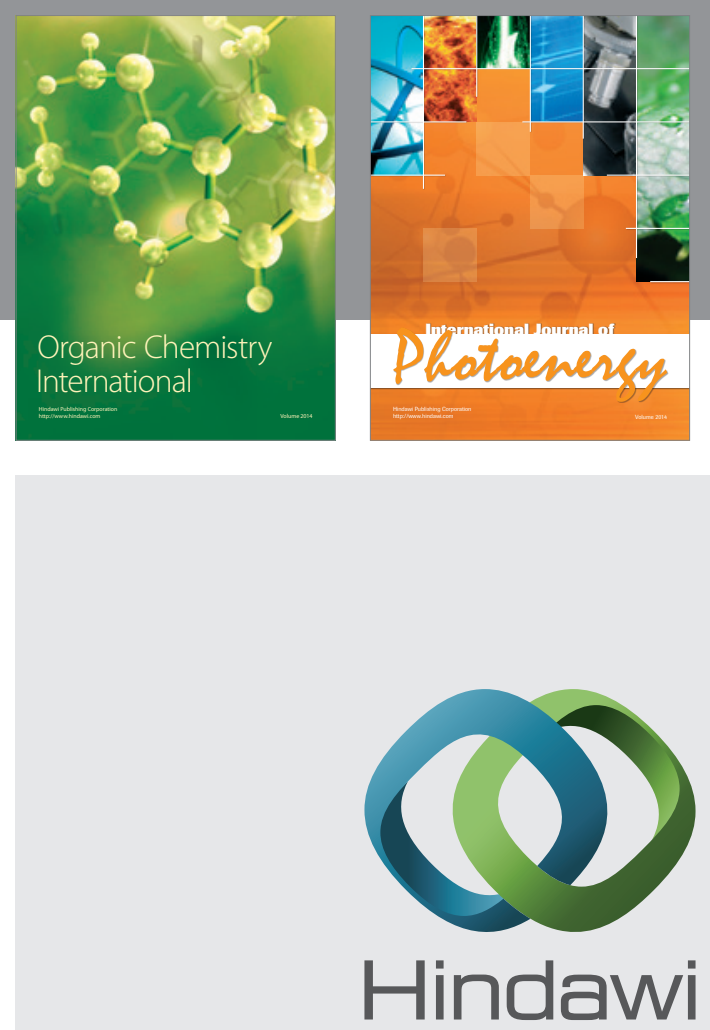

Submit your manuscripts at

http://www.hindawi.com
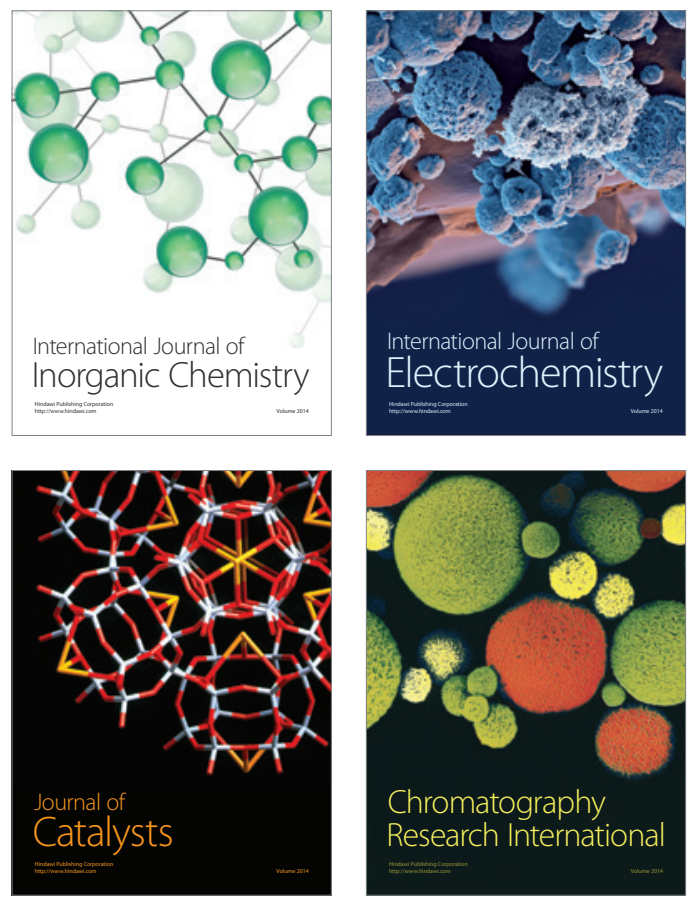
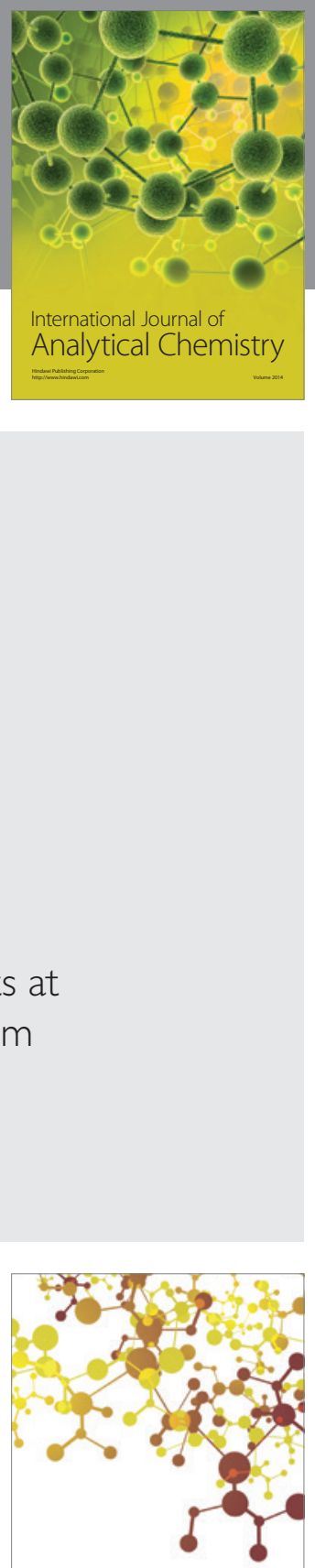

Journal of

Applied Chemistry
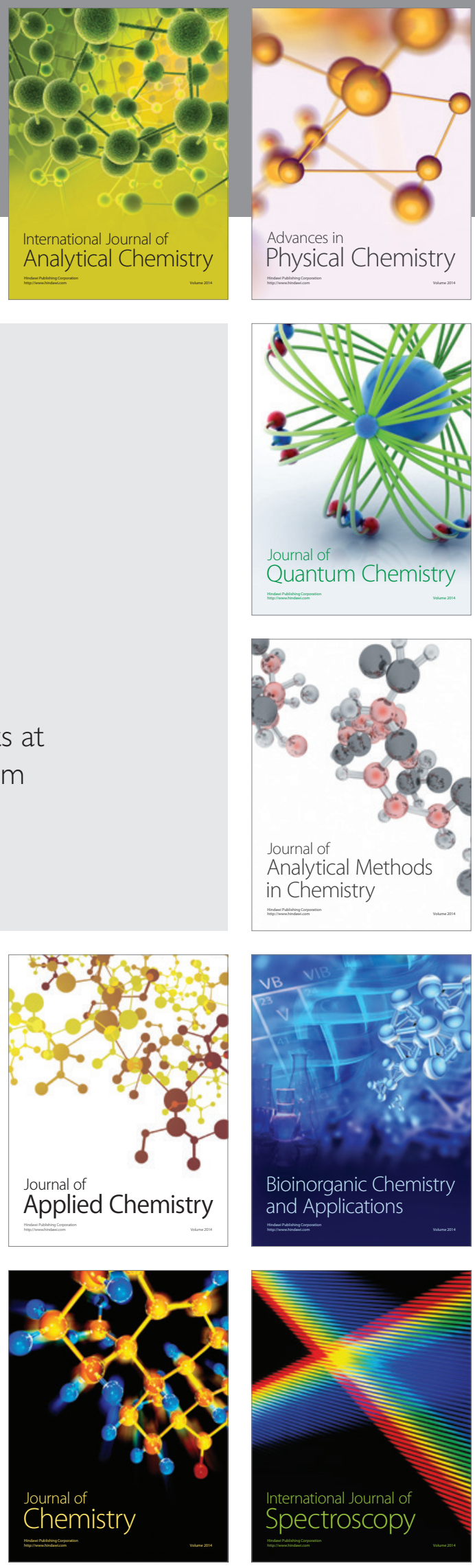